\title{
Micro and Macroeconomic Determinants of Indonesian Government's Bonds Liquidities in the Secondary Market (2012-2016)
}

\author{
Yogie Kristianto Soebagio* \\ Directorate General of Budget Financing and Risk Management, Ministry of Finance, Indonesia
}

\author{
Akhmad Solikin \\ Polytechnic of State Finance STAN, Ministry of Finance, Indonesia
}

\begin{abstract}
Despite having registered the trade volume since 2005, Indonesia's bond market trading and liquidity level in the secondary market are still the lowest in Asia. Neighboring countries like the Philippines and Singapore started registering trading volume records in the same year as Indonesia has exceeded the liquidity level of the Indonesian market. This raises the question of what makes the rate of development in Indonesia's bond market not as fast as other countries in Asia. Therefore, this article aims to analyze the determinants of liquidity in the secondary market of Indonesian bonds, especially government bonds. In the case of Indonesia, research on government liquidity is still limited. Various studies have been conducted to determine the factors affecting liquidity and also the method to calculate them but mostly focus on private bonds. This research uses the level of liquidity of bonds based on turnover ratio as a dependent variable and variable of maturity rate, coupon rate, exchange rate, stock price index, and lending rate as independent variables. The method used is multiple linear regression. The results show that the liquidity of 10 -years benchmark government bonds in Indonesia is significantly influenced by the coupon rate and lending rate positively but influenced by the exchange rate and stock price index negatively. These results indicate that liquidity is influenced by macroeconomic variables. Thus, the Indonesian government should monitor macroeconomic indicators closely and change policy related to its bonds accordingly.
\end{abstract}

JEL: E44, E62, H81

Keywords : Government bond, Liquidity, Secondary market.

\section{INTRODUCTION}

Indonesian government under Joko Widodo administration pursues expansive economic policy by prioritizing infrastructure projects to develop the economy. In 2018, for example, from total national budget of IDR2,220 trillion about IDR410.7 trillion (18.5 percent) were allocated for infrastructure expenditures. Fund availability is crucial for the programs to succeed, especially money from tax revenues. Significantly increasing expenditures without meaningfully increasing tax revenues could lead to a budget deficit.

\footnotetext{
*Email : yogie.soebagio@kemenkeu.go.id

Received : 04-04-2019, Accepted : 09-04-2019, Published : 29-08-2019

P-ISSN : 2087 - 9954, E-ISSN : 2550 - 0066. DOI : http://dx.doi.org/10.26418/jebik.v8i2.32653 
Financing of current national budget deficit is dominated by debt financing. The debt funds are expected to be utilized for productive programs and hence positively affect Indonesian economy. To manage the debts, Ministry of Finance has Directorate General of Budget Financing and Risk Management (Direktorat Jenderal Pengelolaan Pembiayaan dan Risiko, DJPPR) as a unit to manage debt and respective debt risks. The debt management aims at maintaining stakeholders' trusts and avoiding crisis in government finance which can risk national economy. In addition, professional debt management could reduce debt related costs to save public expenditure (Gravelle, 1999).

Gravelle (1999) also pointed out that efficient debt management through liquid secondary financial market would ease government efforts to issue bonds in large denomination in the future but at the relatively low costs. With well debt management, investors feel confidence to buy government's bonds in the primary market and then trade them in the secondary market. Bond liquidity is very important since less liquid bond would increase its issuance costs. Higher issuances costs are caused by the issued bonds are not fully absorbed by markets while full costs have been disbursed. Furthermore, bond liquidity also reflects confidence to the government as the issuer of the bonds reflecting in the transactions of the government issued bonds.

To increase liquidity of government bonds, the government should be able to measure liquidity at the first place and then be able to formulate suitable policies. However, existing facts show that Indonesian bonds liquidity are the lowest in Asia, measured by on the run (i.e. bonds which are currently issued and thus more liquid) as well the second worst in term of off the run (i.e. bonds which are issued in the previous period and hence less liquid) as shown in Table 1. Compared with neighboring countries which also started to mark trading volume in 2005, Indonesia's position is among the lowest by scoring USD 1.72 billion on the run and USD1.30 billion off the run, about similar to the Philippines.

Table 1. Liquidity of Government Bonds (2016, billion USD)

\begin{tabular}{lcc}
\hline \multicolumn{1}{c}{ Country } & On the run & Off the run \\
\hline China & 11.05 & 10.12 \\
Hong Kong & 6.23 & 6.23 \\
Indonesia & 1.72 & 1.30 \\
Myanmar & 4.27 & 3.22 \\
Philippine & 1.81 & 0.86 \\
Singapore & 5.50 & 5.50 \\
Thailand & 3.79 & 2.10 \\
Vietnam & 3.36 & 3.36 \\
\hline
\end{tabular}

Source: (AsianBondsOnline, 2017)

Numerous researches have been conducted to inquire liquidity, both corporates' and governments' bonds, such as researches by He \& Nasser (1999), Choudhry (2009), and Kucuk (2010). These previous researches generally aim at determining factors affecting bond liquidity and finding ways to improve it. However, previous researches use different variables as proxies to measure liquidity as well as implement various independent variables and models. Therefore, their results are different from one another and hence could not directly be concluded for the case of Indonesia. A study by Comelli (2012) found that investors do not put similar weights to country specific and global variables for different time period and different countries. 
As far as authors' knowledge, in Indonesia research about determinant of government bond liquidity is scarce, since previous researches are mainly on government bond's yield (Hutahayan, Widiharih, \& Wilandari, 2015; Paramita \& Pangestuti, 2016), price (Nitasari, Waskita, \& Jalil, 2018; Sukanto, 2009), or demand (Hastin, Idris, \& Aimon, 2013) and corporate bonds liquidities (Dewi, Suhadak, \& Hidayat, 2016; Purnomo \& Puspitasari, 2017). The lack of studies may pose challenges for government to formulate policies to increase government bonds' liquidity since their determinants are not clearly understood, especially in the case of Indonesia. This article aims at filling the research gap by inquiring liquidity of government bonds in secondary market.

\section{LITERATURE REVIEW}

The literature review provides overviews of previous literature with respect to bond liquidity in secondary market, measurement of bond liquidity and each of factors affecting bond liquidity.

\subsection{Importance of Bond Liquidity in the Secondary Market}

In this article, liquidity is defined as a condition where bond transaction can be concluded very fast and trading in large amount does not affect much of both bid ask spread and instrument price (Gravelle, 1999). In addition, Fleming (2003) defined liquid bond market as a market where transaction can be concluded at no cost. Therefore, a market with very low transaction costs can be considered as a liquid market. In practice, bond is issued at the primary market and then traded in the secondary market by dealers. Liquidity reflects an issue for secondary rather than primary market.

Furthermore, Gravelle (1999) argues that liquidity can be defined based on several dimensions namely: (1) immediacy, i.e. time gap between order time and transaction execution at certain volume and price, where the smaller the time gap, the more liquid is the bond; (2) depth, i.e. maximal trade volume for certain bid-ask and does not significantly affect price; (3) resiliency, i.e. how fast price returns to previous or normal level after large volume transaction; and (4) width, i.e. costs needed to provide liquidity. If the cost needed is higher it reflects that the bond is less liquid.

Liquid market is important for corporation as well as government. For the government bond, market wide liquidity is a sovereign variable which is undiversifiable. When market wide liquidity drops, investors will demand compensation in terms of higher premium ( $\mathrm{Li}, \mathrm{Wang}, \mathrm{Wu}$, \& He, 2009). Liquid market improves investors' confidence in buying government bonds in the primary market and then trading them in the secondary market (Gravelle, 1999).

\subsection{Measurement of Bond Liquidity}

There are several methods to measure bond liquidity. In general, methods used to measure liquidity include bid-ask spread, trade volume and trade turnover ratio (D'Souza \& Gaa, 2004). Each method has its own benefits and drawbacks (Fleming, 2003). In Indonesia especially in DJPPR Ministry of Finance, two measures of liquidity are used, i.e. turnover ratio and bid-ask spread. More explanation for turnover ratio and bid-ask spread follows. 
First, turnover ratio is a ratio between trade volume and its outstanding bond. The higher the turnover ratio of a bond, the more active of the bond is traded in the secondary market. Turnover ratio represents depth dimension or the ability of a market to absorb demand and supply of a bond (He \& Nasser, 1999). The formulae to measure turnover ratio is as follows:

Bonds Turn over Ratio $=\frac{\text { Value of Bond Traded }}{\text { Average Amount of Bonds Outstanding }}$

Second, bid-ask spread represents a gap or spread between the highest price consumer wants to pay (or exemplifies demand) and the lowest price a seller wants to sell (or denotes supply). The higher the spread between bid (i.e. demand) and ask (i.e. supply), it represents that the bond is less liquid. On the contrary, the smaller the gap shows that the bond is more liquid. The formulae to calculate bid-ask spread is as follows:

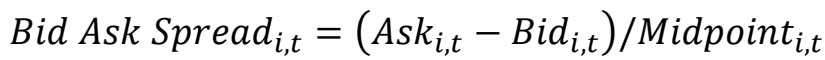

where:

$A s k_{i, t}=$ The lowest price a seller wants to sell (i.e. supply),

$B i d_{i, t}=$ The highest price a consumer wants to buy (i.e. demand).

He \& Nasser (1999) also pointed out that bid-ask spread could be a proxy for liquidity when a seller could not know exactly the true bond price. However, this method has drawback of only valid for certain volume and time (Fleming, 2003). Spread only characterizes one transaction for certain volume and does not represent transactions as a whole.

According to He \& Nasser (1999), factors affecting bond liquidity could be categorize into two groups, i.e. microstructure and macrostructure. Microstructure characterizes a certain bond, such as coupon rate and maturity date; while macrostructure represents condition of national economy, such as inflation rate, exchange rate, stock price index, and interbank lending rate. The followings are more detailed discussions on the effects of each microstructure and macrostructure variables on bond liquidity.

\subsection{Effect of Maturity to Liquidity}

Maturity date is a date when bond principal should be repaid (Fabozzi, 2012). Maturity period or bond tenor varies from short term to longer term. A bond with longer maturity has higher risk and thus coupon rate for bond with longer maturity is generally larger than bond with shorter tenor. Investors charge a higher risk premium on longer tenor bonds than the shorter ones (Broner, Lorenzoni, \& Schmukler, 2013). The higher coupon rate or yield is required to compensate for longer waiting of maturity (Hutahayan et al., 2015).

Choudhry (2009) in the case of UK government bonds, Galliani, Petrella, \& Resti (2014) in the case of Eupean Union, and Pelizzon, Subrahmanyam, Tobe, \& Uno (2018) in the case of Japan government bonds found that maturity correlates positively to liquidity; while Kucuk (2010) in the case of 72 sovereign bonds found negative correlation. Although there is a conflicting results, for a similar bond the shorter period to maturity would make a bond less liquid for trading. Thus, this article hypothesizes that remaining time to maturity correlates positively toward liquidity.

$H_{1}=$ Bond maturity affects positively to government bond liquidity at the secondary market. 


\subsection{Effect of Interest Rate to Liquidity}

Interest rate or usually called coupon rate is value of annual interest payment given to a bond holder during specified active bond period (Fabozzi, 2012). The higher coupon rate will enlarge investor income so the bond will be preferred than the bond with lower coupon rate (Ang \& Piazzesi, 2003). Kucuk (2010) found that coupon rate affect positively to bond liquidity. Therefore, this article posits that coupon rate affects positively to liquidity.

$\mathrm{H}_{2}=$ Coupon rate positively affects liquidity of government bonds in the secondary market.

\subsection{Effect of Exchange Rate to Liquidity}

Foreign exchange rate is the amount of one currency that can be exchanged for other currency or it represents price of one currency to another currency (Fabozzi, 2012). Exchange rate becomes relevant in the bond market since the bond market does not be confined to one country and denominated in one currency. Bonds are issued at various currencies so the exchange rate factors and exchange rate risks are factors should be considered diligently by investors (Fabozzi, 2012).

He \& Nasser (1999) pointed out that when direct quotation of local currency toward foreign currency strengthens then foreign investors will invest more in the country. If investment increases then it will escalates bond liquidity in the country. On the contrary, if exchange rate fluctuates, it will induce investors to pull their investment from the country due to increasing exchange rate risks. Increasing exchange rate risks would affect projected income uncertainty for foreign investors. However, exchange rate impacts on liquidity could be small if foreign investors only hold small number of government bond.

$H_{3}=$ Exchange rate affects negatively on government bond liquidity in the secondary market.

\subsection{Effects of Stock Price Index on Liquidity}

Stock price index is an index that reflects price movement in certain period. Stock price index is an important benchmark for an investor to invest in stock market, especially for trading stocks to acquire capital gain. However, association between stock price index and bond market is inversely related, since the two investments instruments compete each other (He \& Nasser, 1999). For example, when stock price decreases it will increase bond yield and thus make investment in bond become more interesting for investor. Increasing government bond yield could be perceived as an increase in the investor wealth or could also be seen as a worsening public (Afonso \& Sousa, 2011). The latter case will make investment in government bond perceived as more risky and in turns reduce liquidity of the government bonds.

However, there is a situation when stock price index correlates positively to bond market. For example, Choudhry (2009) used stock price index as a measure for overall market confidence. The stock price index used in his research was The Financial Times Stock Exchange 100 Index (FTSE-100), i.e. index of 100 companies listed in the London Stock Exchange which have highest capitalization. The research results show that FTSE-100 affects positively to bond liquidity in the secondary market in the UK. In Indonesia Stock Exchange (IDX), composite stock price index is called Indeks Harga Saham Gabungan (IHSG).

$H_{4}=$ IHSG affects positively on government bond liquidity in the secondary market. 


\subsection{Effect of Interbank Interest Rate to Liquidity}

Interbank offered rate is an interest rate offered from one bank to another and also represents borrowing rate accepted from on bank to another. In Indonesia interbank lending and borrowing rate is JIBOR (Jakarta Interbank Offered Rate) with various tenors such as one day, one week, one month, three months, six months and twelve months. The change in interbank offered rate will affect bond market since investors rely on banking system to get funding or used it compare financing costs. Interbank offered rate is used as benchmark in getting funds, lending funds, as well as repaying loan (He \& Nasser, 1999). The higher the interbank offered rate will cause bond market becomes less liquid since investors will hold their funds due to higher financing costs. Both Choudhry (2009) and Kucuk (2010) used interbank offered rate as an independent variables in their studies and found that interbank offered rate affects negatively on bond liquidity. Thus the fifth hypothesis in this article is as follow.

$H_{5}=$ JIBOR affects negatively on government bond liquidity in the secondary market.

Based on previous discussions, microstructure variables used in this article are maturity and coupon rate which are expected to have positive correlations with government bond liquidity. As for macrostructure variables, there are exchange rate, stock exchange index, and interbank offered rate. Exchange rate and interbank offered rate are expected to have negative influence toward liquidity; while stock price index is expected to have positive effect to liquidity. The research framework is shown in Figure 1.

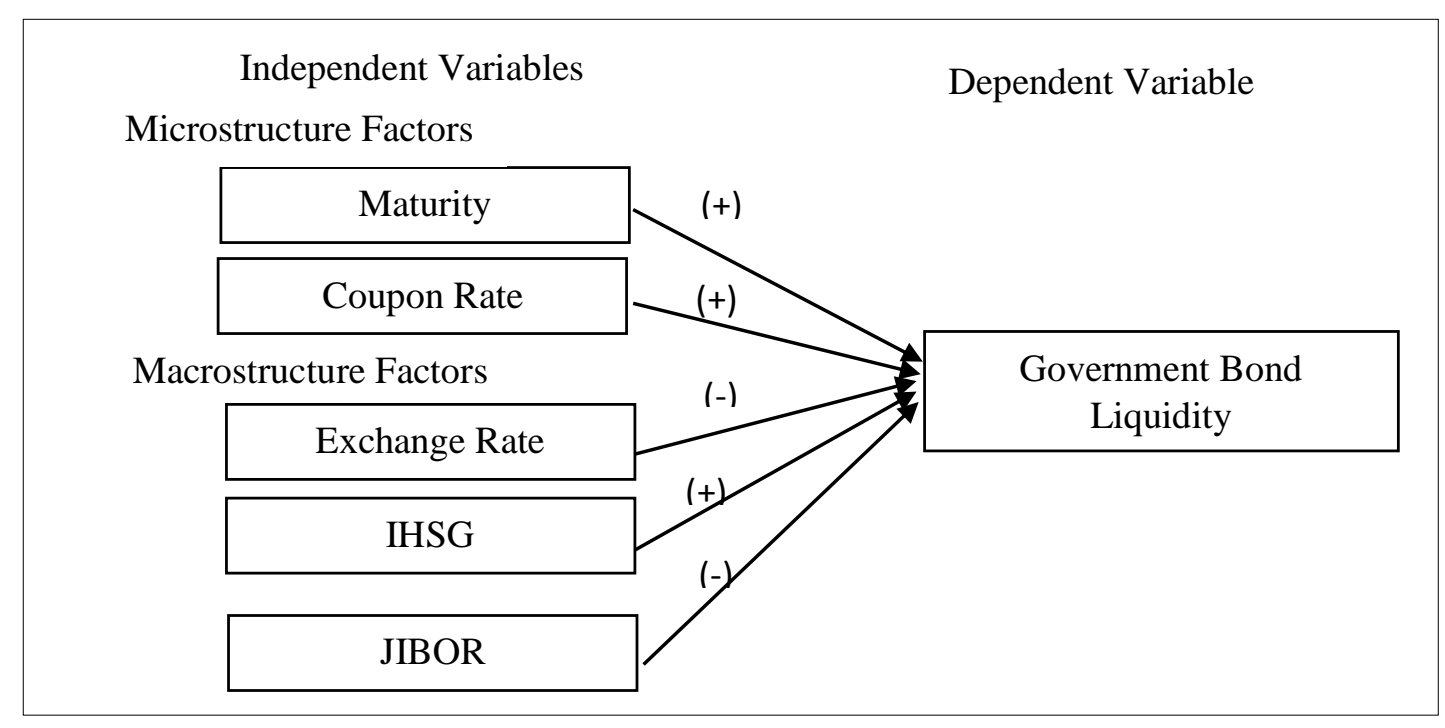

Figure 1. Research Model

\section{RESEARCH METHODS}

This article is a quantitative research by using secondary data. Monthly data from January 2012 to December 2016 were obtained from DJPPR Ministry of Finance (Kemenkeu, 2017), Bank Indonesia, and Bloomberg. As previously explained, five independent and one dependent variable are used in this article. Data of turnover ratio, maturity date, and coupon rate were obtained from 
DJPPR Ministry of Finance. Data of JIBOR were obtained from Bank Indonesia (2017). Data of exchange rate and IHSG were obtained from (Bloomberg, 2017a, 2017b).

More explanation about the variables and data used are as follows. First, dependent variable of government bond liquidity is measured by the turnover ratio. In this article, the turnover ratio is measured as ratio between bonds trade volume and outstanding bonds for monthly period. Therefore the data contain monthly ratio from January 2012 to December 2016. During the periods, there were four series of benchmark bonds with coupon 7 percent, 5.625 percent, and 8.375 percent, as shown in Table 2.

Table 2. Benchmark Bonds Series with 10 Years Tenor

\begin{tabular}{ccc}
\hline Year & Series & Coupon Rate (\%) \\
\hline 2012 & FR0061 & 7.000 \\
2013 & FR0063 & 5.625 \\
2014 & FR0070 & 8.375 \\
2015 & FR0070 & 8.375 \\
2016 & FR0056 & 8.375 \\
\hline
\end{tabular}

Source: Processed from DJPPR data

Second, remaining time from maturity is gap between maturity date and the specific date of each month from January 2012 to December 2016. Third, coupon rate is coupon at the issuance date and valid until maturity date. Fourth, exchange rate is value of direct quotation on USD toward IDR at the end of each month. Data used were median exchange rates. Fifth, IHSG data used were index at the last working day in each month. Lastly, JIBOR data used were JIBOR rate one for month tenor. Descriptive statistics of raw scores are presented in Table 3.

Table 3. Descriptive Statistics of Raw Scores

\begin{tabular}{lrrrrrr}
\hline & TURN & \multicolumn{1}{c}{ TERM } & COUPON & \multicolumn{1}{c}{ EXCH } & \multicolumn{1}{c}{ IHSG } & JIBOR \\
\hline Mean & 0.7308 & 3505.52 & 0.07550 & $11,734.80$ & $4,719.53$ & 0.06275 \\
Minimum & 0.23 & $2,997.00$ & 0.05625 & $8,998.00$ & $3,832.82$ & 0.03985 \\
Maximum & 1.92 & $3,880.00$ & 0.08375 & $14,653.00$ & $5,518.68$ & 0.08552 \\
Sum & 43.85 & $210,331.00$ & 4.53000 & $704,088.00$ & $283,171.56$ & 3.76476 \\
Range & 1.70 & 883.00 & 0.02750 & $5,655.00$ & $1,685.85$ & 0.04567 \\
Std. Deviation & 0.34683 & 212.86 & 0.01109 & $1,666.88$ & 446.51 & 0.01346 \\
Variance & 0.120 & $45,309.58$ & 0.00012 & $2,778,477.55$ & $199,373.06$ & 0.00018 \\
Skewness & 1.238 & -0.652 & -0.86554 & -0.259 & -0.124 & -0.22318 \\
Kurtosis & 1.648 & -0.135 & -0.89650 & -1.361 & -1.050 & -1.20877 \\
$\mathrm{~N}$ & 60 & 60 & 60 & 60 & 60 & 60 \\
\hline
\end{tabular}

Furthermore, usual classical assumption tests or Gaus-Markov test were conducted, i.e. normality test, heteroscedasticity test, autocorrelation test, and multicollinearity test. Normality test aims to inquire whether regression model, errors or residual have normal distribution. Normality test was carried out using Kolmogorov-Smirnov test. It turns out that the error of raw scores were not normal. Several methods to tackle problem of normality include adding more data, deleting outliers, or data transformation (Santoso, 2012). Several methods of transformation data exist such as using square root, logarithm, natural logarithm, or differencing (Field, 2009; Santoso, 2012). The variables are all transformed in natural logarithm and the transformation reduced the positive Saw (Field, 2009). The data after transformation is presented in Table 4. 
Table 4. Descriptive Statistics of Transformed Scores

\begin{tabular}{lrrrrrr}
\hline & TURN & \multicolumn{1}{c}{ TERM } & COUPON & EXCH & \multicolumn{1}{c}{ IHSG } & \multicolumn{1}{c}{ JIBOR } \\
\hline Mean & -0.4158 & 8.16 & -2.59 & 9.36 & 8.45 & -2.79 \\
Minimum & -1.48 & 8.01 & -2.88 & 9.10 & 8.25 & -3.22 \\
Maximum & 0.65 & 8.26 & -2.48 & 9.59 & 8.62 & -2.46 \\
Sum & -24.95 & 489.61 & -155.72 & 561.60 & 507.30 & -167.58 \\
Range & 2.14 & 0.26 & 0.40 & 0.49 & 0.36 & 0.76 \\
Std. Deviation & 0.45605 & 0.06214 & 0.15876 & 0.14645 & 0.09580 & 0.22591 \\
Variance & 0.208 & 0.004 & 0.025 & 0.021 & 0.009 & 0.051 \\
Skewness & 0.008 & -0.782 & -0.957 & -0.384 & -0.260 & -0.464 \\
Kurtosis & -0.010 & 0.046 & -0.704 & -1.331 & -0.980 & -1.119 \\
$\mathrm{~N}$ & 60 & 60 & 60 & 60 & 60 & 60 \\
\hline
\end{tabular}

After transformation, normality test by using Kolmorgorov-Smirnov results significance value is 0.20 (statistic $=0.073, \mathrm{df}=60$ ) which is higher than 0.05 . Furthermore, Shapiro-Wilk test results significance value of 0.819 (statistic $=0.988, \mathrm{df}=60$ ) which is higher than 0.05 . Therefore the two tests show that transformed data fulfils normality test.

As for heteroscedasticity test, the test is important to make sure that variance of residuals are similar (Santoso, 2012). If the variances are not similar, it is called heteroscedastic and could make inefficient estimator while having higher determination coefficient (Priyatno, 2013). Using Glejser test, it shows that transformed data has is homoscedastic.

As for autocorrelation tests, it aims at testing whether residuals from one period correlates with residuals of previous period (Ghozali, 2016). The good regression requires there is no autocorrelation in the data. Durbin-Watson test score was $1.420(\mathrm{df} 1=5, \mathrm{df} 2=54)$, which means no conclusion can be reached. Further test using runs test produce score 0.602 which is greater than 0.05 . Therefore, from the run test it can be concluded that there is no autocorrelation in the transformed data.

Regarding multicollinearity, the best regression should make sure that independent variables have correlation with dependent variable but do not have correlation with other independent variables. Correlation test between independent variables show that the highest correlation score is between exchange rate and JIBOR (i.e. score $=0.816$ ) which is below 0.9 threshold (Ghozali, 2016). Further tolerance and variance inflation factor (VIF) tests reveal that the higher tolerance score is natural logarithm of maturity (score $=0.784$ ) and the highest VIF score is 4.729 for natural logarithm of exchange rate. Both scores show that multicollinearity does not exist since the score is above 0.1 for tolerance and below 10 for VIF cut off scores, respectively (Ghozali, 2016).

After satisfied with Gaus-Markov theorem tests, regression analysis was carried out. Equation (3) shows empirical model tested in this study. The time series model was analyzed by using SPSS 22 software.

$$
\begin{aligned}
& L N_{-} T U R N B 10_{i t}=\beta_{0}+\beta_{1} L N_{-} T E R M_{t}+\beta_{2} L N_{-} C O U P O N_{t}+\beta_{3} L N_{-} E X C H_{t}+\beta_{4} L N_{-} I H S G_{t}+ \\
& \beta_{5} L N_{-} J I B O R_{t}+\varepsilon_{t}
\end{aligned}
$$

Note: 
$L N_{-} T U R N B 10_{t}=$ natural logarithm of turnover ratio of benchmark bonds with tenor 10 years in period $\mathrm{t}$,

$L N_{-} T E R M_{t} \quad=$ natural logarithm of remaining time until maturity in period $\mathrm{t}$,

$L N_{-}$COUPON $_{t}=$ natural logarithm of coupon rate at absolute value in period $\mathrm{t}$,

$L N_{-} E X C H_{t} \quad=$ natural logarithm of exchange rate in period $\mathrm{t}$,

$L N_{-} I H S G_{t} \quad=$ natural logarithm of IHSG in period $\mathrm{t}$,

$L N_{-} J I B O R_{t} \quad=$ natural logarithm of JIBOR rate in period $\mathrm{t}$,

$\beta_{0} \quad=$ intercept,

$\varepsilon_{t} \quad=$ error.

Since the empirical model is a log-log model, the interpretation of regression results should be a $1 \%$ of change in the independent variable is associated with $\beta_{\mathrm{j}} \%$ change in the dependent variable (Stock \& Watson, 2011).

\section{RESULTS AND DISCUSSIONS}

\subsection{Regression Results}

The regression results are shown in Table 5. The table shows that F-statistic score is 8.154 with probabilistic score is 0.000 . It means that the model is statistically significant at 1 percent and thus $\mathrm{F}$ test reveals that the model can be used to explain influence of independent variables to dependent variable (Iqbal, 2015). In this article, it means that maturity, coupon rate, exchange rate, IHSG and JIBOR could explain variation in the government bond liquidity. However, the combination of independent variables could only explain 37.7 percent of government bond liquidity as justified from score of adjusted R squared.

Table 5. Regression Results

\begin{tabular}{lcccc}
\hline Variables & $\begin{array}{c}\text { Standardized } \\
\text { Coefficients }\end{array}$ & t-Statistic & Sig. & \\
\hline (Constant) & \multicolumn{5}{c}{2.801} & 0.007 & \\
LN_TERM & 0.191 & 1.650 & 0.105 & $*$ \\
LN_COUPON & 0.257 & 1.842 & 0.071 & $* * *$ \\
LN_EXCH & -0.815 & -3.648 & 0.001 & $* *$ \\
LN_IHSG & -0.327 & -2.562 & 0.013 & $* * *$ \\
LN_JIBOR & 0.527 & 2.906 & 0.005 & \\
R-Squared & 0.43 & & \\
Adj R-Squared & 0.377 & & \\
F-Statistic & 8.154 & & \\
Prob (F-Statistic) & 0.000009 & \\
Note: *** = significant at 1\%, **= significant at 5\%, * significant at $10 \%$ &
\end{tabular}

Note: $* * *=$ significant at $1 \%, * *=$ significant at $5 \%, *=$ significant at $10 \%$

Source: Authors analysis with SPSS 22

Among five independent variables, four variables are significant, i.e. coupon rate (significant at 10 percent), exchange rate (statistically significant at 1 percent), IHSG (statistically significant at 5 percent), and JIBOR (statistically significant at 1 percent). One independent variable, i.e. remaining time to maturity is not significant.

Seeing from the standardized coefficient, independent variable which has the highest effect on government bond liquidity is exchange rate (coefficient $=-0.815$ ). As for signs of the coefficients, three independent variables (i.e. maturity, coupon rate, and exchange rate) have 
coefficient signs as expected in hypotheses; while two independent variables (i.e. IHSG and JIBOR) have coefficient signs which are contrary to hypotheses. Thus, hypothesis H1 is not verified because of insignificant t test. Furthermore, hypothesis $\mathrm{H} 2$ and $\mathrm{H} 3$ are verified; while hypothesis $\mathrm{H} 4$ and $\mathrm{H} 5$ are not verified due to different coefficient signs from expectations.

\subsection{Discussion of Research Results}

From regression it turns out that bond maturity does not significantly affect government bond liquidity at the secondary market. Thus, investors may not take into account the remaining maturity time in trading benchmark government bond. Investors may consider other factors such as coupon rate, exchange rate, IHSG and JIBOR. This result contradicts with numerous previous researches (Choudhry, 2009; Galliani et al., 2014; Kucuk, 2010; Pelizzon et al., 2018).

Coupon rate affects positively toward benchmark government bonds liquidity with 10 years tenor which is measured by turnover ratio. It means that investors consider coupon rate which influence bond yield when they buy the government bonds. The higher coupon or interest rate will give higher yield to bond holders (Paramita \& Pangestuti, 2016). Especially in condition of limited funds, government bond with higher coupon rate will be actively traded than the one with lower coupon rate with similar remaining time to maturity. Positive correlation indicates that the higher coupon rate will increase demand of the bond. The higher demand will increase trade volume and finally it will stimulate bond liquidity. The result is in line with previous literature.

Exchange rate negatively affects government bond liquidity and is statistically significant at 99 percent. Exchange rate is much related to foreign investors' participation since exchange rate is an important consideration when investing in a foreign country, whether investing in stocks or bonds. If local currency as bond denomination depreciates or losses value, it will reduce income from the bond (Fabozzi, 2012). Stronger direct exchange rate will reduce liquidity so that its influence is negative. Exchange rate risk will reduce return value both in terms of periodic interest payments as well as principal payment. The reduction of yield will reduce investor appetite to invest in secondary market. To compensate the reduction of yield, investor will choose bond with higher yields.

Furthermore, independent variable of IHSG negatively affects sovereign bond liquidity and it is statistically significant at 95 percent. The result differs to expectation in which previous hypothesis expect positive relationship, i.e. increasing stock price index will increase government bond liquidity (Kucuk, 2010). In the hypothesis, it is expected that stock price index represents an indicator of macroeconomic condition and a yardstick for confidence to the financial system of a country. According to this preposition, stronger stock price index reflects capacity to cope with economic crisis. In addition, higher market capitalization combined with stronger exchange rate represents robust economic condition and it in turns will attract foreign investors to bring money to stock market as well as bond market.

Previous literature could shed some lights on the cause of the phenomenon. For example, Naik \& Padhi (2012) point out that stock market becomes alternative of bond market in the condition of high inflation rate. Investors will consider to place or move their funds from bond market to stock market when inflation rise. If stock market risk increase, and investors have different risk appetite and investment horizon become long term, then investors will likely to choose bond market rather than stock market. Crisis in financial market affects income in the stock 
market, or even it causes capital loss. In this situation, bond market is more attractive and secure and may provide higher returns due to fixed income payment in terms of interest income and principal repayment at maturity. Investors could wait stock market recovery by holding bonds. Therefore, there is inverse relationship between stock market and bond market, i.e. when stock market bearish, bond market tends to bullish, including affecting liquidity of bond market which is influenced by bond trading volume. On the contrary, when crisis occurs in the stock market, investor will seek more stable financial instrument, i.e. bond market (He \& Nasser, 1999).

Lastly, JIBOR has positive effect on liquidity at 99 percent statistical significance. JIBOR represents borrowing rate which offered from one bank to another and also lending rate which is accepted from one bank to another. The higher interest rate will increase bond trade volume because yield received by investor will also increase. The result of this study contradicts with Choudhry (2009) which found that negative relationship between data spread of LIBOR 3 month and government bond yield. When LIBOR rate increase, it will increase risk in bond market. Furthermore, investors will hold their fund and thus it will reduce bond liquidity.

To explain discrepancy with previous literature, it should be noted that higher JIBOR risk correlates with increasing investors' income bring about by the growing risk. Fabozzi (2012) states that there is bond which uses floating coupon in which coupon measurement is linked to LIBOR margin. Therefore, the higher the LIBOR rate will raise investor income. This study finds that JIBOR positively correlates to turnover. It means that investors are interested to trade bond in secondary market because JIBOR increase will raise their income in association with raising bond risk.

\section{CONCLUSION}

Based on previous discussions, it can be concluded several conclusion regarding independent variables. First, coupon rate positively affects liquidity of benchmark government bonds of 10 years tenor. Second, remaining time to maturity does not affect the government bonds liquidity. Third, exchange rate negatively correlates with the government bond liquidity at 99 percent of statistical significance. Fourth, IHSG is statistically proved to negatively affect the sovereign bonds liquidity at 95 percent level. Lastly, JIBOR affects the government bond liquidity at 99 percent of statistical significance. The sign of correlation of JIBOR and liquidity is positive.

From the results, in general from two microstructure variables only one variable (i.e. coupon rate) is significant. On the other hand, all macrostructure variables in this model are significant, albeit there are independent variables which their coefficient signs are different from expectations. These results underscore the importance of macroeconomic variables in explaining determinants of government bond liquidity. The result is similar to Ang \& Piazzesi (2003) who found that macroeconomic factors contribute to $85 \%$ of the variations as well as Ahwireng-Obeng (2016) in the case of 26 African countries. The result is also similar with the case of corporate bonds, as documented in Nigerian bond market (Nkwede, Uguru, \& Nkwegu, 2016).

For future research, several research avenues are identified. The result show that adjusted $\mathrm{R}^{2}$ is below 50 percent which shows that there exist other variables which may affect liquidly of government bonds. Alternative variables which can be incorporated in the model include foreign participation in bond market (Ebeke \& Lu, 2015), the use of IT system such as Electronic Trading 
Platform (ETP), number of dealers and brokers, impact of government bond buyback, number of government debt (Gao, Jin, \& Thompson, 2018), sovereign credit rating (Michel \& Solikin, 2019), and debt switch. Psychological impacts in terms of behaviors of investors and impacts of rumors or news or announcements to bond market in Indonesia are also some topics or variables for future research. Several examples include D'Souza (2004) in the case of Canada government bonds or Tsuchida, Watanabe, \& Yoshiba (2016) in the case of macroeconomics indicators and monetary policy announcements in Japan.

Based on the results, several suggestions for government abound. The Indonesian government, especially Ministry of Finance, should consider coupon rate which is suitable to energize liquidity of government bonds in the secondary market. The coupon rate should be sufficiently high to attract investors but too high to add substantially interest costs which may reduce expenditures for other productive public sectors. In addition, the government should monitor market condition regularly, i.e. IHSG condition in the IDX and as well as JIBOR condition. Both variables could affect liquidity and represent market trust from domestic and foreign investors. Unfavorable fluctuations of IHSG and JIBOR may signal an incoming crisis. Favorable IHSG and JIBOR would improve government bond liquidity in the secondary market. However, the government should manage risks related to substantial volume of foreign funds in the domestic financial market.

\section{BIBLIOGRAPHY}

Afonso, A., \& Sousa, R. M. (2011). Consumption, Wealth, Stock and Government Bond Returns: International Evidence. The Manchester School, 79(6), 1294-1232. https://doi.org/https://doi.org/10.1111/j.1467-9957.2011.02247.x

Ahwireng-Obeng, S. A. (2016). Performance Determinants of Local Currency Bond Markets in African Emerging Economies. University of the Witwatersrand, (April).

Ang, A., \& Piazzesi, M. (2003). A No-Arbitrage Vector Autoregression of Term Structure Dynamics with Macroeconomic and Latent Variables. Journal of Monetary Economics, 50(4), 745-787. https://doi.org/10.1016/S0304-3932(03)00032-1

AsianBondsOnline. (2017). Data Portal. Retrieved September 5, 2017, from https://asianbondsonline.adb.org/

Bloomberg. (2017a). Currencies. Retrieved December 5, 2017, from https://www.bloomberg.com/markets/currencies

Bloomberg. (2017b). Stocks. Retrieved December 5, 2017, from https://www.bloomberg.com/markets/stocks

Broner, F. A., Lorenzoni, G., \& Schmukler, S. L. (2013). Why Do Emerging Economies Borrow Short Term? Journal of the European Economic Association, 11(suppl_1), 67-100. https://doi.org/https://doi.org/10.1111/j.1542-4774.2012.01094.x

Choudhry, M. (2009). The Value of Introducing Structural Reform to Improve Bond Market Liquidity: Experience from the U.K. Gilt Market. European Journal of Finance and Banking Research, 2(2), 13-35. 
Comelli, F. (2012). Emerging Market Sovereign Bond Spreads: Estimation and Back-Testing. Emerging Markets Review, 13(4), 598-625. https://doi.org/https://doi.org/10.1016/j.ememar.2012.09.002

D’Souza, C. (2004). Liquidity in the Market for Government of Canada Bonds: An Empirical Analysis. In Financial System Review. Ottawa: Financial System Review Bank of Canada.

D’Souza, C., \& Gaa, C. (2004). The Effects of Economic News on Bond Market Liquidity. Ottawa.

Dewi, N. P. E. A., Suhadak, \& Hidayat, R. R. (2016). Pengaruh Visibilitas Obligasi, Perbedaan Opini, dan Asimetri Informasi Terhadap Likuiditas Obligasi di PT Bursa Efek Indonesia (Studi pada Sektor Perbankan yang Menerbitkan Obligasi di PT BEI Periode 2013-2015 ). Jurnal Administrasi Bisnis (JAB), 33(1), 197-204.

Ebeke, C., \& Lu, Y. (2015). Emerging Market Local Currency Bond Yields and Foreign Holdings - A Fortune or Misfortune? Journal of International Money and Finance, 59, 203-219. https://doi.org/https://doi.org/10.1016/j.jimonfin.2015.07.006

Fabozzi, F. J. (2012). Bond Markets, Analysis and Strategies (8th ed.). New Jersey: Pearson Education.

Field, A. P. (2009). Discovering Statistics Using SPSS (and Sex and Drugs and Rock " $n$ " Roll) (3rd ed.). Los Angeles: SAGE Publications.

Fleming, M. J. (2003). Measuring Treasury Market Liquidity (pp. 83-108). pp. 83-108. New York: Federal Reserve Bank of New York Economic Policy Review.

Galliani, C., Petrella, G., \& Resti, A. (2014). The Liquidity of Corporate and Government Bonds: Drivers and Sensitivity to Different Market Conditions. In Joint Research Centre Techinical Reports of the European Commision. https://doi.org/10.2788/70146

Gao, J., Jin, J., \& Thompson, J. (2018). The Impact of Government Debt Supply on Bond Market Liquidity: An Empirical Analysis of the Canadian Market. In Bank of Canada Staff Working Paper 2018-35 (No. 35). https://doi.org/10.2139/ssrn.3176181

Ghozali, I. (2016). Aplikasi Analisis Multivariate dengan Program IBM SPSS 23 (8th ed.). Semarang: Badan Penerbit Fakultas Ekonomi Universitas Diponegoro.

Gravelle, T. (1999). Liquidity of Government of Canada Securities Market: Stylized Facts and Some Market Microstructure Comparisons to The United States Treasury Market (No. 99). Retrieved from https://www.bankofcanada.ca/wp-content/uploads/2010/05/wp99-11.pdf

Hastin, M., Idris, \& Aimon, H. (2013). Analisis Pasar Obligasi Pemerintah di Indonesia. Jurnal Kajian Ekonomi, I(2), 241-258.

He, W., \& Nasser, T. (1999). An Empirical Study on the Factors Affecting Bond Liquidity in the Thai Secondary Bond Market. ABAC Journal, 19(3), 46-65.

Hutahayan, E. S., Widiharih, T., \& Wilandari, Y. (2015). Pembentukan Kurva Imbal Hasil Yield dengan Model Nelson Siegel-Svensson (NSS) Studi Kasus Data Obligasi Pemerintah Periode 27 Oktober 2014 Sampai 31 Oktober 2014). Journal Gaussian, 4(3), 477-484. 
Indonesia, B. (2017). Historical data of IndONIA and JIBOR. Retrieved December 5, 2017, from https://www.bi.go.id/en/moneter/jibor/data-historis/Default.aspx

Iqbal, M. (2015). Pengolahan Data Regresi Linear Berganda dengan EViews 8. Jakarta: Perbanas Institute.

Kemenkeu. (2017). Profil Utang dan Penjaminan Pemerintah Pusat Bulan Januari 2017. Jakarta: Direktorat Jenderal Pengelolaan Pembiayaan dan Risiko, Kementerian Keuangan.

Kucuk, U. N. (2010). Dynamic Sources of Sovereign Bond Market Liquidity (No. MPRA Paper No. 25642).

Li, H., Wang, J., Wu, C., \& He, Y. (2009). Are Liquidity and Information Risks Priced in the Treasury Bond Market? The Journal of Finance, 64(1), 467-503. https://doi.org/https://doi.org/10.1111/j.1540-6261.2008.01439.x

Michel, G., \& Solikin, A. (2019). The Determinants of Sovereign Credit Ratings Indonesia and Its Neighborhood Countries 1998-2016. AGREGAT: Jurnal Ekonomi Dan Bisnis, 3(1), 46-57. https://doi.org/10.22236/agregat_vol3/is1pp46-57

Naik, P. K., \& Padhi, P. (2012). The Impact of Macroeconomic Fundamentals on Stock Prices Revisited: Evidence from Indian Data. Eurasian Journal of Business and Economics, 5(10), 25-44. Retrieved from https://www.ejbe.org/EJBE2012Vol05No10p25NAIK-PADHI.pdf

Nitasari, D., Waskita, J., \& Jalil, M. (2018). Pengaruh Suku Bunga Deposito, Nilai Tukar dan Inflasi Terhadap Harga Obligasi Pemerintah yang Terdaftar di Bursa Efek Indonesia Periode 2011-2017. Permana, 9(2), 1-20.

Nkwede, F. E., Uguru, L. C., \& Nkwegu, L. C. (2016). Corporate Bond Market Development in Nigeria: Does Macroeconomic Factors Matter? Arabian Journal of Business and Management Review (Oman Chapter), 6(2), 25-45. https://doi.org/10.12816/0033273

Paramita, R. P., \& Pangestuti, I. R. D. (2016). Determinan Yield Obligasi Pemerintah Tenor 5 Tahun dengan Menggunakan Model EGARCH pada Negara Indonesia, Malaysia, Thailand dan Filipina. Diponegoro Journal of Management, 5(3), 1-14.

Pelizzon, L., Subrahmanyam, M. G., Tobe, R., \& Uno, J. (2018). Scarcity and Spotlight Effects on Liquidity and Yield: Quantitative Easing in Japan. In (Institute for Monetary and Economic Studies (IMES) Bank of Japan. https://doi.org/10.2139/ssrn.3107603

Priyatno, D. (2013). Analisis Korelasi, Regresi dan Multivariate dengan SPSS. Yogyakarta: Gava Media.

Purnomo, E., \& Puspitasari, N. (2017). Pengaruh Likuiditas, Kupon, Jangka Waktu Jatuh Tempo dan Suku Bunga Pasar Terhadap Harga Pasar Obligasi Berperingkat Rendah dan Harga Pasar Obligasi Berperingkat Tinggi. Relasi: Jurnal Ekonomi, 13(1), 34-49. https://doi.org/http://dx.doi.org/10.31967/relasi.v13i1.104

Santoso, S. (2012). Aplikasi SPSS pada Statistik Multivariat. Jakarta: Elex Media Komputindo.

Stock, J. H., \& Watson, M. W. (2011). Introduction to Econometrics Third Edition (3rd ed.). Boston: Addison-Wesley. 
Sukanto, E. (2009). Pengaruh Suku Bunga Deposito, Kurs Rupiah-USD, Tingkat Inflasi, IHSG dan Volume Transaksi Terhadap Harga Obligasi Pemerintah RI (SUN). Fokus Ekonomi, 4(2), 9-23.

Tsuchida, N., Toshiaki Watanabe, \& Toshinao Yoshiba. (2016). The Intraday Market Liquidity of Japanese Government Bond Futures. In IMES Discussion Paper Series. Retrieved from https://www.imes.boj.or.jp/research/papers/english/me34-3.pdf 